\section{British Columbia}

\section{Curriculum Development}

UBC's Faculty of Forestry is engaged in developing a five-year plan. Task forces have been formed to investigate the following topics:

(1) a revision of the undergraduate curriculum;

(2) the development of an international forestry program;

(3) an expansion of professional forestry education at the post-baccalaureate level; and

(4) the development of a program of continuing eduation studies in forestry.

The Faculty is also exploring a major new program in parks and natural areas centered around the principles of conservation biology.

\section{Hungarian Graduates Recognized}

Thirty-four years after Hungary's uprising, the 141 graduates of Sopron's Forestry Faculty (who completed their forestry degrees as the Sopron Division at UBC) were officially accepted as members of the Sopron University Alma Mater. Drs. Tony Kozak (Associate Dean and Professor in Forest Resources Management) and Laszlo Paszner (Professor in Harvesting and Wood Science) travelled to Hungary to take part in the official reinstatement ceremonies held on November 4, 1990.

\section{Harvesting and Wood Science Department}

Dr. R. W. Kennedy will be a visiting Professor at the School of Agriculture and Forestry at the University of Melbourne in Australia for the months of February through April 1991. While in Australia, he will take part in a week-long Wood Science course for executives and forest industry consultants. He will also review the activity of the Australian Resource Assessment Commission which has a mandate to "... review forestry in all its aspects as a resource', and compare their conclusions with those of the B.C. Forest Resources Commission.

The Hon. Claude Richmond, Minister of Forests and his Deputy Mr. Phil Halkett, visited the Department in December for a briefing on the Forest Operations and Wood Science research programs. Presentations made by faculty members demonstrated their broad range of interests. Opportunities exist for developing interdisciplinary teams at UBC to address forest management, forest harvesting and resource utilization research needs currently being identified by the B.C. Forest Resources Commission and Green Plan proposals.
Forest Sciences Department

The SCHIRP (Salal/Cedar/Hemlock Integrated Research Program) has received a further two years of funding from the NSERC Research Partnership Program. The industry cooperators are Western Forest Products, MacMillan Bloedel and Fletcher Challenge Canada. This will bring the 1991 funding total to over $\$ 300,000$.

Susan B. Watts Ph.D., R.P.F.

\section{Forest Economics and Policy Analysis Research Unit}

A major emphasis in FEPA's computer modelling work is to assist Forestry Canada with the development and use of state-ofthe-art computer models for policy analysis. The technical programming support group is led by Susan Phelps who is also in charge of technology transfer for the FEPA Research Unit.

One of the important continuing projects undertaken by FEPA within this joint research program involves the development of a methodology for analysing the economics of Canadian timber supply. This project focuses on the evaluation of timber supply models, the development of a variety of data bases for these models and, where necessary, an expansion or modification of these models to improve their use for policy analysis in Canada.

To meet the overall objectives of a study of the economics of future regional timber supply, the analyst must be able to forecast over a particular planning horizon both the existing timber inventory and the volume of timber that can be removed from the area. Since the rate at which timber can be harvested is dependent on the demand for that timber (among other economic factors), the analyst must also be able to simultaneously examine the market for timber products. Furthermore, both the inventory and the market must be represented in as much detail as possible, capturing all the major influences on both components, without straining available computer and human resources.

While long-term national timber supply studies have been carried out for over a hundred years in the U.S., it is only since the 1960's that this type of analysis has been undertaken for Canada and only recently that computer-based models developed by U.S. and Canadian researchers have taken into account the influence of economic factors on the level of available timber supply. Recent modelling efforts emphasize the importance of these factors in inventory projection, harvest scheduling and timber supply, as well as the prediction of activity levels in the forest industry and in international trade of forest products. FEPA was originally established to facilitate the use of policy models which recognize the importance of economic factors in forestry decision making in Canada. This continues to be one of the most important missions of the Unit.

As part of this effort, FEPA evaluated a variety of models for Forestry Canada's national timber supply study. This process involved (1) installing the key models used in the U.S. and Europe on selected computer systems; (2) running the models with sample data bases to ensure correct installation; (3) developing prototype data bases to explore features of the models most relevant to the national timber supply study; (4) where necessary, modifying the models to include unavailable features; and (5) developing comprehensive data bases to accommodate these enhancements and modifications.

Aggregate timber supply models provide the most appropriate framework for investigating the long-run timber supply situation for an area the size of Canada. The dominant feature of these models is their ability to forecast timber inventories over long periods of time for fairly large timberland areas stratified by region, age class, site class, species, and management intensity. Many of these models use tables of growth and yield information, which permit the inclusion of a growth response delay mechanism, to project timber inventory. Other features include the ability to control land shifts between various management regimes, to remove timber volumes from existing inventories through harvesting and other processes, and to invest in the timber resource, permitting harvest levels to be determined internally. These are the main elements of the aggregate timber supply models evaluated by FEPA.

The Timber Resource Inventory Model (TRIM) is one of the inventory projection models adapted by FEPA for Canadian users. It is also one of a set of procedures developed by the USDA Forest Service for use in periodic national timber resource assessments. Its main strength lies in the level of inventory detail that may be utilized and in its ability to shift timberland areas between alternative management intensities. The use of TRIM in studies of Canadian timber supply is somewhat limited, however, due to the fact that harvest levels cannot be determined internally, losses to the inventory through pest and fire outbreaks are not taken into account, and economic elements, such as price, must remain static over time. Nevertheless, it is a significant improvement over previous inventory projection models which could not monitor 
changes in land management. A more thorough discussion of TRIM based on an extensive evaluation of the model is contained in FEPA Working Paper \#123.

The Price-Responsive Timber Supply Model (PRTSM) developed by D.H. Williams, formerly of FEPA, is a significant extension of the TRIM methodology. The PRTSM includes all the features of TRIM plus the ability to determine harvest quantities from levels of current economic activity. In this model, the inventory must be divided into growing stock and old growth categories, with the latter further divided into one-dollar cost classes. This feature implies that the interaction between the biological and economic components of a region's inventory is known, involving an enormous amount of detailed inventory data which must be collected. In support of Forestry Canada's national timber supply study, a comprehensive data base of the British Columbia interior was prepared by FEPA for use with the PRTSM. The model is currently undergoing further development and thus is not available, but the theoretical basis for this work can be found in a study of the economic stock of timber on the B.C. coast, detailed in FEPA Report 86-11.

The B.C. Silviculture Planning Model (FOREST) developed by a team of FEPA associates is another aggregate timber supply model. As described in last August's column, the objective of this model is to provide a framework for investigating the biological and economic effects of alternate silvicultural investments. However, by altering its focus somewhat, the model could easily be adapted for use in the national timber supply study. The main strengths of this model are its detailed accounting of land shifts between alternative management regimes and treatment categories and the short- and long-run economic effects of investing in the timber resource. In addition, the impact on the inventory of both fire and pest outbreaks and the cost of these activities is included in significant detail. Like TRIM, however, the model cannot determine desired harvest levels. FEPA Working Paper \#147 provides a brief description of the model and a demonstration of its use in evaluating silvicultural strategies. In addition, several unpublished technical papers are available from FEPA.

With the exception of the PRTSM, the major limitation of these timber supply/ inventory projection models is their inability to adequately account for the influence of market forces on the rate at which timber can be removed from an area. An alternative approach emphasizes the market for forest products, where that market has access to an available timber supply. By capturing and projecting the interaction between the demand for and the supply of major forest products in a modelling framework, the derived demand for timber can be determined and this information passed to an inventory projection model. The choice is then whether to "soft" link these models, that is, use inputs from market models as exogenous variables in the timber supply models, or to include the market model and the timber supply model together in one large modelling framework.

Calculating the derived demand for timber for an area the size of Canada with the diversity of timber supply available requires that the regional nature of the industry be recognized and included. Areas specializing in softwood lumber production, for example, must be acknowledged as being distinct from areas capable of producing only hardwood woodpulp, but both regions must be included when studying national timber supply. International trade must also be taken into account since Canada's position as a net supplier of forest products is determined in the international marketplace. Furthermore, the available inventory must continue to be described in sufficient detail. All of these features are present to various degrees in the market models evaluated by FEPA.

Like TRIM, the Timber Assessment Market Model (TAMM) was developed by the USDA Forest Service for use in periodic national timber resource assessments. This model represents the applied state-ofthe-art in aggregate U.S. timber supply modelling with its technique of incorporating short-run supply (harvest) decisions and long-run investment planning in a spatial equilibrium framework. TAMM uses simulation techniques to forecast price, consumption and production trends (from one to five decades) in the North American softwood lumber, plywood and U.S. strumpage markets. Timber demands generated by the pulp and paper industry, by fuelwood consumption and by miscellaneous product production (e.g. particleboard) are also considered, but the level of these demands is determined outside of the model.

An initial examination of TAMM by FEPA indicated that the major drawback of the model for use in national timber supply analyses was its treatment of Canada as a single softwood lumber supply region, with both domestic and offshore demand for Canadian forest products determined exogenously. Under the auspices of Forestry Canada, FEPA expanded the Canadian representation in TAMM by disaggregating the supply region into six softwood lumber, plywood and timber supply regions and by introducing five Canadian product demand regions. Details of the modifications made to TAMM for the development of the North American Timber Assessment Market Model (NATAMM) and a description of the associated data are contained in FEPA Report 86-15.

The main feature of NA-TAMM is that it is a much more comprehensive model of the North American forest products industry than TAMM. Its limitations are the TRAS inventory projection system used for U.S. regions and its current, simplistic representation of Canadian timber supply. To address the latter, FEPA recently linked NA-TAMM to a version of the PriceResponsive Timber Supply Model and applied this system to a preliminary analysis of the supply of timber on the B.C. coast. The linkage between these models, along with the mathematical structure of NA-TAMM, is described in an unpublished FEPA technical report.

The Price-Endogenous Linear Programming System (PELPS) is the third analytical system developed by the USDA Forest Service used in periodic U.S. timber resource assessments and is the basis for the model of the North American pulp and paper industry currently under development by Canadian and U.S. forest services. The mathematical technique defined by PELPS was initially used in the Pulp and Paper Market Model (PPMM), the system developed by the USDA Forest Service to provide estimates of timber demand by the U.S. pulp and paper industry for TAMM. A comprehensive Canadian data base for the PPMM was prepared by FEPA and is described in three unpublished FEPA reports, while instructions for using the model are contained in FEPA Report 86-7. An overview of the North American pulp and paper industry is presented in FEPA Report 85-11.

Like TAMM, PELPS combines shortterm supply decisions with long-term investment planning in a spatial equilibrium framework. However, PELPS uses optimization rather than simulation techniques to forecast long-term trends in the production, consumption and price of a variety of pulp and paper products, ranging from raw materials such as softwood roundwood and intermediate products such as semichemical pulp, to final products such as newsprint and paperboard. Recycled commodities are also included.

One of the unique features of PELPS is that it can be applied to any economic sector. The general nature of the model also implies that the level of detailed analysis performed by the model is directly related to the level of detailed data provided to it.

FEPA's contribution to the development of a model of the North American pulp and paper industry includes improving the user interface and the reporting features of PELPS II PLUS, the most recent addition to the PELPS family of models. When complete, this model will also provide the national timber supply study with forecasts of the level of timber demanded by the North American pulp and paper industry.

Most of the software described here along with technical documentation may be obtained without charge from FEPA. For further information, or to receive FEPA's biannual newsletter, please write: FEPA Research Unit, University of British Columbia, \#468 - 2206 East Mall, Vancouver, B.C. V6T 1 Z8. 


\section{Laval}

Programme coopératif en sciences du bois

Le Conseil de l'Université Laval a accepté, à titre expérimental pour cinq ans, la proposition de modification du régime des études pour le programme en sciences du bois. Il s'agit du premier programme coopératif ou régime en alternance travail-études accepté par le Conseil de l'Université.

\section{Nominations}

Jim Dangerfield, vice-président de la division de l'Est de Forintek Canada Corp., est heureux d'annoncer les nominations de Marco Grondin et Jean-Pierre Mongeau comme chercheurs scientifiques du groupe Forintek à l'Université Laval. La création du groupe Forintek à l'Université Laval résulte d'un protocole d'entente pour créer un Centre d'excellence en transformation du bois de petites dimensions. Les recherches du Centre portent sur le développement de modèles informatiques permettant de simuler et d'optimizer les opérations dans l'industrie du bois de sciage.

Lancement d'un programme de recherche et d'enseignement gradué en économie forestière

Au cours des deux dernières années, le Groupe de recherche en économie de l'énergie et des ressources naturelles (*GREEN), la Faculté des sciences sociales et la Faculté de foresterie et de géomatique ont mis sur pied un programme visant à favoriser la recherche et les études graduées en économie forestière. Ce projet a reçu l'appui de cinq partenaires: Forêts Canada (25 000\$), Ministère Energie et Ressources Québec (25 000\$), Association des industries forestières du Québec (10 000\$), Association des manufacturiers de bois de sciage du Québec (10 000\$), Fédération des producteurs de bois du Québec $(6000 \$)$. Cet appui, d'un montant total de $76000 \$$ pour 1990-91, sera normalement renouvelable pour chacune des quatre prochaines années.

Un premier projet de recherche sur l'établissement de la valeur des bois sur pied sera réalisé conjointement par Claude Godbout et Luc Bouthillier du département des sciences forestières et par Jean-Thomas Bernard et Martin Luckert du département d'économique.

\section{Chercheur postdoctoral}

Hans-Peter Rensch, diplôme de l'Institut für Chemische Technik de Karlesruhe en Allemagne vient se joindre, à titre de chercheur post-doctoral, à l'équipe de Bernard Riedl du département des sciences du bois. Il travaillera pour une période de deux ans, en tant que membre du centre de recherche en sciences et en ingénierie des macromolécules (CERSIM). Il effectuera ses recherches sur la caractérisation fondamentale de surface et de composites à base de bois.

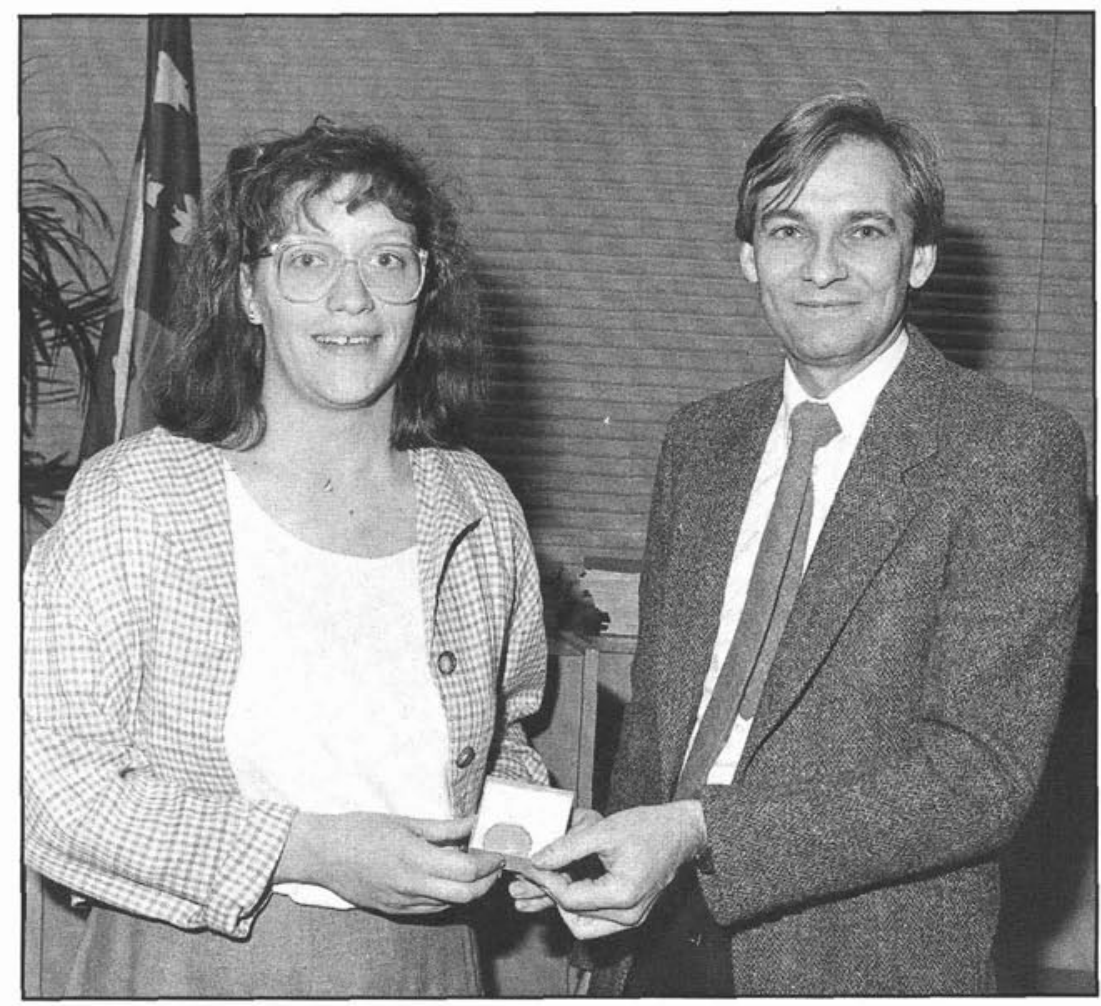

Le 12 décembre dernier, l'Institut forestier du Canada tenait une cérémonie à l'intention des finissants en foresterie. L'Institut a profité de l'occasion pour remettre sa médaille d'or à Solange Nadeau, une finissante s'étant particulièrement illustrée par ses résultats académiques et par sa participation à la vie facultaire. On la voit ici recevant son prix des mains du professeur Luc Bouthillier représentant l'Institut forestier du Canada (section Orléans). L'Institut a également remis un jonc aux 52 finissants et finissantes de la Faculté.

\section{Diplomation aux $2 \mathrm{e}$ et $3 \mathrm{e}$ cycles}

Onze étudiantes et étudiants de la Faculté ont obtenu leur diplôme de maîtrise ou de doctorat depuis septembre 1990. Les sujets des mémoires de maîtrise et des thèses de doctorat des diplômés ont été les suivants:

\section{Sciences du bois}

Halim Chtourou (M.Sc.). Valorisation des plastiques recyclés par addition de fibres de bois. Directeur: B. Riedl. Co-directeur: A.A. Kadi.

Bernard Huot (M.Sc.). Effet de la vitesse sur la précision du classement par machine de bois de charpente non homogènes. Directeur: M. Samson.

\section{Sciences forestières}

Robert Boutin (M.Sc.). Effets de l'acidification in vitro d'un podzol ferrohumique sur la chimie des percolats et des horizons. Directeur: C. Camiré.

Richard Caissy (M.Sc.). Gestion de l'irrigation de plants forestiers à racines nues. Directeur: J. Stein. Co-directeur: A. Plamondon.

Cheikh Oumar Diop (M.Sc.). Les conditions de participation des populations au reboisement communautaire - cas du projet de boisement villageois de Louga (Nord-Sénégal). Directeur: M. Pineau. Co-directeur: C. Beauchamp.

Tahir dit Abdoulaye Diop (M.Sc.). Méthodes axéniques de production d'inocula endomycorhiziens à vésicules et arbuscules: étude avec le Gigaspora margarita. Directeur: Y. Piché. Co-directeur: J.-A. Fortin.

Alain Dupont (M.Sc.). Relations empiriques entre la vulnérabilité du sapin baumier à la tordeuse des bourgeons de l'épinette et les caractéristiques écologiques des sapinières. Directeur: L. Bélanger.

Harry Kope (Ph.D.). Antagonistic properties of ectomycorrhizal fungi: detection efficacity and variation in the production of antifungal compounds by Pisolithus arhihizus. Directeur: J.-A. Fortin.

Géodéon Munyarugerero (M.Sc.). Étude du dépérissement du cyprès (Capressus lasitanica Mill.) au Rwanda: caractérisation des sites affectés dans la zone de la crète Zaïre-Nil. Directeur: M. Pineau. Co-directeur: C. Camiré.

Papa N'Diaye (M.Sc.). Étude des caractéristiques de croissance du Casuarina equisetifolia forêt dans la zone du litoral nord du Sénégal. Directeur: M. Pineau. 
Alice Roy (M.Sc.). Analyse du polymorphisme de restriction (RFLP) de l'ADN génomique d'isolats du champignon anamorphe entomopathogène Paecilomyces farinosus (Holm ex Grey) Brown \& Smith. Directeur: J.-A. Fortin. Co-directeur: D.F. Perry.

Bourses de la Compagnie Abitibi Price et de la Compagnie de papier Québec et Ontario

Le 10 décembre 1990 avait lieu la remise officielle des deux bourses au montant de $3500 \$$ chacune de Abitibi-Price Inc. Les récipiendaires sont deux étudiants gradués de deuxième cycle: Jean Bissonette et Martine Hamel.

Barbara Arnault et Marjorie Lebreux étudiantes en aménagement des ressources forestières, ont reçu une bourse d'études de premier cycle de la Compagnie de papier Québec et Ontario. Ces bourses, d'une value de $\$ 500$ chacune, sont renouvelables jusqu'à la fin des études des étudiantes. Ces bourses sont offertes aux étudiants originaires de la Côte-Nord qui présentent un dossier académique adéquat.

Marie R. Coyea

\section{New Brunswick \\ Forestry Alumni News}

' 80 Jeffrey Patch (BScF) was appointed regional resource manager for the Miramich area with the NB Department of Natural Resources and Energy and will oversee the administration of 10 district ranger offices. With the department since 1980 , he was previously director of wildlife management.

'62 Gordon B. Young (BScF, MF'72), and Robert L. Kenny (BA '66, BCL '68) were honored by the Fredericton North Rotary Club at a dinner in September with a Paul Harris Fellowship Award in recognition of their ongoing contributions to the community. They co-chaired the fundraising campaign for Fredericton's new indoor pool. Mr. Young served on the District 26 Board of School Trustees for many years and has been the school board representative on the maintenance and operations committee for the Nashwaaksis Field House since its beginning. He has served on the executives of several forestry and appraisal organizations and is president of Woodlot Service (1978) Ltd. in Fredericton.

' 52 George B. Bailey (BScF) of Espanola, Ont., retired Aug. 1. He was vice-president, forestry and wood products for E.B. Eddy Forest Products Ltd.

\section{Graduate Theses Available}

The following graduate theses, produced during the August-November, 1990, period, may be borrowed from the Faculty of Forestry's Continuing Education Office (see address at end of this article):
"A Simulation Study of a Stochastic Restrictions Regression Approach to Volume Equation Estimation" (Yue Wang, $\mathrm{MScF})$.

"Effects of Forest Floor Disturbance on Seedbanks, Germination and Early Survival of Woody Species after Clearcutting of Northern Tolerant Hardwoods in Central New Brunswick" (Hongyun Dong, $\mathrm{MScF})$.

"A GIS Database Design for Forest Management: A Case Study"' (Wardoyo, MF). "Analysis of the Simple Ellipse as a Basic Fire Growth Model"' (Ertugrul Bilgili, $\mathrm{MScF})$.

"Spatial Wood Supply Modelling: Concept and Practice" (Emin Baskent, MScF).

"Variation of Some Properties of a Plantation-Grown Red Pine"' (Sencer Alkan, MScFE).

"Variation in Some Properties and Effect of Moisture on Clear Wood from a Red Pine", (Fikret Kaya, MScFE).

"Genetic Variation of Black Spruce Seedlings in Response to Different Forms of Aluminum Phosphate"' (John Cruickshank, MScF).

\section{Faculty Briefs}

Professor C.A. Short, Forest Engineering, has been appointed to the Steering Committee on Fire Safety and Fuel Burning Equipment of the Canadian Standards Association.

$$
* * *
$$

Assistant Dean D.A. Daugharty chaired the executive meeting of the NRC's associate committee on hydrology in Ottawa on November 23, 1990.

$$
* * *
$$

Professor R.A. Douglas, Forest Engineering, presented a paper at the December 20 meeting of the American Society of Agricultural Engineers in Chicago. The paper was entitled "Practical Use of Truck Performance Models".

Professor Douglas will also be involved in an exchange program ("Going Global, Europe '92) with R.M. Hay of the British Forestry Commission under the auspices of External Affairs and International Trade, Canada. Douglas will be in Edinburgh for 10 days while Hay will be in Frederiction and Montreal for three days.

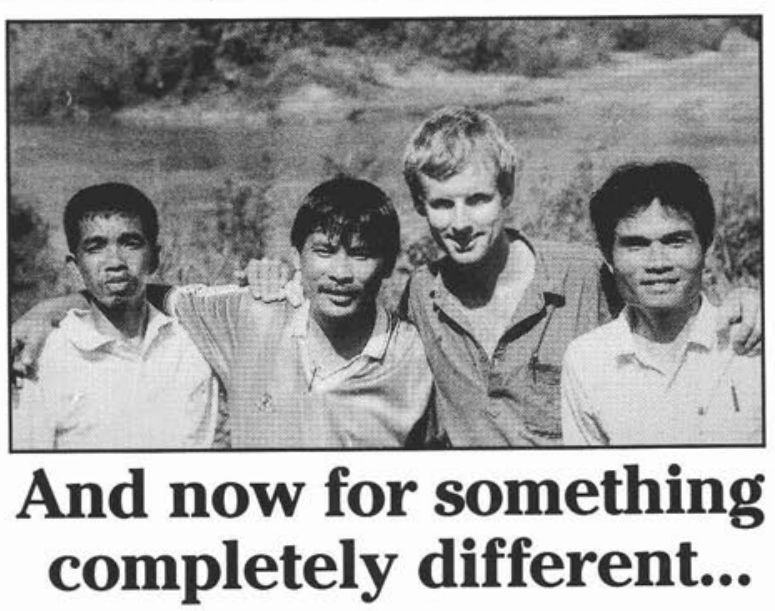

We can't offer fast food, supermarkets, 9-to-5, and traffic jams. But we can offer you the chance of a lifetime.

Two years living in another culture and an opportunity to work with others who are striving to improve their lives. It's hard work, but rewarding.

We need someone special. Someone with skills and experience to share. Someone who can live on a modest salary. If you are a forester, fisherman, soil scientist, park planner or environmentalist, we may have a job for you.

For further information please send your résumé to: CUSO DA-18c, 135 Rideau St., Ottawa, Ont. K1N 9K7

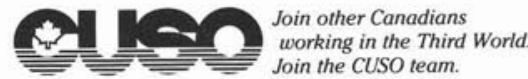


Canada Scholar Named in Forestry

Second-year forestry student Christine P. Wellings of Brookfield, Nova Scotia, was among the 130 outstanding young men and women at UNB who have been named Canada Scholars during the last three years, and who were saluted by university and government representatives at a recent reception sponsored by the faculties of computer science, forestry and engineering.

Canada scholars, in addition to a commemorative pin and a certificate of merit signed by the Prime Minister of Canada, each receive an annual award of $\$ 2,000$. This may be renewed up to a maximum $\$ 8,000$. which goes towards defraying the cost of undergraduate studies in the natural sciences, engineering and related disciplines. A minimum of 50 per cent of the scholarships are allocated annually to women.

The Canada Scholarships Program was established to help meet Canada's need for more scientists and engineers to secure a place in the first rank of nations in the $21 \mathrm{st}$ century. In today's world economy, success is largely determined by scientific and technological adaptability and responsiveness. Canada currently ranks second to last among industrialized nations in the number of researchers per thousand workers - which is generally used as an indicator of a country's capacity to invent and innovate.

\section{A Tree should live a Tubex ${ }^{\star}$ sheltered life.}

\section{Tubex Treeshelters give your tree seedlings their best chance for survival three ways. 1. Tubex ${ }^{\bullet}$ creates a warm, humid micro- climate accelerating early growth of the tree 5 to 6 times over that of an unsheltered tree dus- ing the first 2 years. \\ Faster growth means a greater chance for surviral. \\ 2. Tubex Treeshelters are tall enough to act as an excellent guard against browse, mice, rabbits, deer and other herbivores looking for a free lunch from your \\ young trees. Tubex's cylindrical design allows wind to travel easily around the shelter keeping the tree inside protected. 3. Tubex Treeshelters make weed-control hastle-free. Herbicides can be applied quickly and safely around the treeshelter with no risk of damage to the tree seedling. \\ For rapid tree growth, shelter against animals and wind and protection from herbicides use Tubex Treeshelters. And let your trees live a sheltered life. \\ For more information on Tubex ${ }^{\bullet}$ Treeshelters write, fax or phone: \\ The St. George Co. Ltd. 206 McPherson School Rd.} St.George, Ontario Canada NOE 1N0 Phone: 519-442-2046 Fax: 519-442-7191

\section{Continuing Education}

The following educational events will be conducted April through June, 1991:

$$
\text { *** }
$$

1. April 9 and 10, 1991 (registration deadline: March 15, 1991) - "Ergonomic Applications in Forestry".

This course defines, details and discusses the fundamental human factors which affect the health and efficiency of operators working in an industrial environment. Particular emphasis is placed on the application of current knowledge and methodology to forest operations. It is intended for operations managers, machine maintenance supervisors, or human relations officers.

Enrollment and Fee: Limited to 20 persons. If fewer than 10 persons enroll, the workshop may be cancelled. The fee is $\$ 145$. (Canadian) per person.

$$
\text { *** }
$$

2. June 4 and 5, 1991 (registration deadline: May 10, 1991) - "Identification of Shrubs and Ground Vegetation of Importance to Forestry in New Brunswick".

It is important that technicians and foresters involved in site classification be able to identify some of the common forest plants. This course is designed to accomplish this.

The course will deal with easily visible features of the plants and will not concentrate on minute features, botanical descriptions or scientific names. The species studied will be largely the same as those contained in the Field Guides to Forest Site Classification in New Brunswick, a series of six booklets currently being published by the Department of Natural Resources and Energy. Species covered will come from among the shrubs, ferns and fern allies, herbs, grasses and sedges, and mosses, liverworts and lichens.
Almost all of the time will be spent in the field where instructors will lead in identifying the various species and will point out the distinguishing features of each. A complete set of notes will be provided. These notes will show a drawing of each species, will give a description of the features of leaves, twigs, flowers and fruit, as appropriate, and will give additional information on the significance that each species has in a forest context.

This course is intended for foresters dealing with site classification, wildlife habitat, regeneration problems, etc.

Enrollment and Fee: Up to 20 persons may enroll. If fewer than 12 register, the workshop may be cancelled. The fee is $\$ 220$. (Can.) per person.

The location for all the above events will be the Maritime Forest Ranger School wing of the Hugh John Flemming Forestry Centre, Fredericton.

\section{For Sale}

Proceedings of the 1990 Balsam Fir Update. This is a professionally prepared and printed record of technical information on a range of useful Christmas tree topics. It is available for $\$ 5.00$.

\section{Further Information}

If you need further information about anything listed above, please don't hesitate to contact: Coordinator of Continuing Education in Forestry, University of New Brunswick, Bag Number 44555, Fredericton, New Brunswick, Canada E3B 6C2. Phone (506) 453-4501, Fax: (506) 453-3538.

\section{Obituaries}

Alex Dickson

\section{Ian C. MacQueen 1909-1990}

Ian C. MacQueen, retired consulting forest engineer, President and Director, Forestal Forestry and Engineering Limited, 1960-1974, died in late October, 1990. Mr. MacQueen graduated from the University of British Columbia in 1934 and undertook post-graduate studies at the University of California in 1938. Mr. MacQueen became a Registered Professional Engineer, British Columbia, Forest Engineering in 1946, a Registered Professional Forester in British Columbia in 1947 and in New Brunswick in 1965 . He was a member of the Canadian Institute of Forestry.
Mr. MacQueen worked in Forest Surveys and in Fire Control with the British Columbia Forest Service between 1926 and 1940. From 1941 to 1945 he was in the Royal Canadian Air Force. In $1946 \mathrm{Mr}$. MacQueen joined Western Plywood Company Ltd. in Quesnel, where he was Resident Manager. From 1958 to 1963 he was a Lecturer in Industrial Forest Management at the University of British Columbia. From 1957 until his retirement, Mr. MacQueen worked in forest consulting, first as President, I. C. MacQueen Ltd., and second with Forestal. Mr. MacQueen is survived by his wife, Joan, two daughters, a sister and grandchildren and great-grandchildren. 